\title{
Determinants of Participation Decision in Cassava Marketing by Smallholder Farmers in Taita-Taveta and Kilifi Counties, Kenya
}

\author{
Amos Nyangira Tirra ${ }^{1}$, Willis Oluoch-Kosura ${ }^{1}$, Hillary Nyanganga ${ }^{1}$ \& Agnes W. Mwang'ombe ${ }^{2}$ \\ ${ }^{1}$ Department of Agricultural Economics, University of Nairobi, Nairobi, Kenya \\ ${ }^{2}$ Department of Plant Science and Crop Protection, University of Nairobi, Nairobi, Kenya \\ Correspondence: Amos Nyangira Tirra, Department of Agricultural Economics, University of Nairobi, Nairobi, \\ Kenya. E-mail: amostirra@gmail.com
}

\author{
Received: June 1, $2019 \quad$ Accepted: August 23, $2019 \quad$ Online Published: October 15, 2019 \\ doi:10.5539/jas.v11n17p98 URL: https://doi.org/10.5539/jas.v11n17p98
}

\begin{abstract}
Cassava is an important food crop with high production potential in different agroecological zones across the world. Cassava is also a drought tolerant crop performing well in arid and semi-arid areas. Cassava has a great potential as both a food security and industrial crop. In addition, as a drought tolerant crop, it is fits very well as a climate smart crop in the face of climate change. However, the cassava industry and value chain in Kenya is still underdeveloped and therefore there are many cassava marketing opportunities that are yet to be exploited. This study analyses factors that influence smallholder farmers' decision to participate in cassava marketing in Taita-Taveta and Kilifi Counties in Kenya. Data was collected using semi-structured questionnaires from a sample of 250 smallholder cassava farmers. Descriptive statistics were used to analyse the socio-economic characteristics of respondents while a binary Probit model was used to analyse the socio-economic factors that influence farmers' participation decision in cassava marketing. The results of the binary Probit model show that, sex of the head of a household, access to extension services, price of cassava products and quantity harvested had a positive and significant influence on market participation decision while years of schooling, household size and farm size had a negative and significant influence on the market participation decision. Therefore, based on the findings, the study recommended policy interventions targeting organization and coordination of the cassava marketing system and provision of appropriate incentives to farmers to enhance market participation.
\end{abstract}

Keywords: cassava, farmers, Kenya, marketing, participation decision

\section{Introduction}

Cassava (Manihot esculenta) is one of the most popular and widely consumed food crops in Africa. It was introduced to sub-Saharan Africa (SSA) in the sixteenth century by Portuguese traders from Brazil (Koplez; IITA, 2009). Its production has since then spread to 40 of the 54 countries in Africa and this accounts for approximately 61 percent of global production (Dunstan \& Chuma, 2017). The leading cassava producers in SSA are; Nigeria (59 million MT), DRC (32 million MT), Ghana (18 million MT), Angola (12 million MT), and Mozambique (9 million MT) respectively (FAOSTAT, 2017). Cassava is therefore commonly referred to as cornerstone of food security in Africa due to its importance as a source of food for many people and adaptability to diverse ecological conditions in the region. According to YPARD (2014) report, cassava plant produces excellent harvests in adverse conditions even when other crops have failed. The report shows that, cassava is also becoming an important raw material for industrial production due to its competing need in production of food, starch, animal feed and biofuels. In addition, the rapid population growth in Africa has led to increased demand for staple foods like cassava leading to improved livelihood of several smallholder farmers in the cassava business.

In Kenya, cassava farming is practiced on approximately 90,394 hectares of land throughout the country producing about 1,112,000 MT per year. Consequently, its productivity stands at $12.3 \mathrm{MT} / \mathrm{ha}$ which is far much below the potential 50MT/ha (FAOSTAT, 2017). Cassava production is concentrated in the Coastal, Central and Western regions of Kenya. About 90 percent of cassava produced in Kenya is consumed as food and therefore there is need to increase its production in order to expand its value chain to meet other industrial requirements including animal feed, starch and ethanol production as processing cassava increases the net benefits earned. Besides, cassava is an advantageous crop since it fits varied farming and food systems as well as it has a high yielding 
ability and it is easy to cultivate hence it has low labour requirements. Moreover, it is relatively tolerant to low soil fertility and drought, and it can remain in the ground for over two years without spoilage; making it an ideal famine reserve crop (Koplez; IITA, 2009). However, according to KAPAP (2012), the production and utilization of cassava in Kenya remains unexploited despite all this potential. Furthermore, its production is characterized by low use of inputs, use of poor/basic technology, large post-harvest losses, minimum value addition, unreliable supply, low quality of products, low producer prices, costly marketing structure and low utilization of cassava in the industrial sector.

There are many households at the Kenyan coast that participate in cassava marketing. Households can participate in the cassava market from the demand side as buyers or from the supply side as sellers. Market participation is based on the optimization theory since households are rational and they aim at maximizing their utility subject to their budget constraint and non-tradable constraints (Burrett, 2008). Therefore, just like any other profit-making business, farmer's decision to participate in the cassava market depends on the profit margins, thus only those farmers who expect to benefit net of costs, from cassava farming will choose to participate in the cassava market. According to De Janvry et al. (1991), Goetz (1992), and Key et al. (2000), many households fail to participate in the commodity market due to high transaction costs and market failure. In addition, high transaction costs and imperfect markets makes it costly to discover marketing opportunities and therefore, poor market access increases the cost of the product or service leading to reduced household participation in the market (Enete \& Igbokwe, 2009).

Taita-Taveta and Kilifi counties are semi-arid areas and therefore, residents of these areas are frequently hit by hunger due to drought. On the other hand, cassava has been viewed as a solution to this problem due to its potential of doing well where other crops have failed and in different agroecological zones. Therefore, there is need to understand different factors that influence household participation in cassava marketing from the supply side in order to inform policy geared towards introducing incentives focused on the given factors. Motivating farmers to increase the production of cassava in the area would help to solve the hunger problem during drought as well as increasing participation in cassava marketing.

\section{Methodology}

\subsection{Study Area}

The study was carried out in Taita-Taveta and Kilifi counties located at the coastal parts of Kenya. Taita-Taveta county covers a geographical area of $17,083.9 \mathrm{~km}^{2}$ of which 62 percent is within Tsavo East and Tsavo West National Parks. The remaining 38 percent is occupied by ranches, wildlife sanctuaries, sisal estates, water bodies, hilltop forests and it is also used for residential purposes and other human activities. The county's altitude ranges from $500 \mathrm{~m}$ to $2,228 \mathrm{~m}$ above sea level and has a population of approximately 274,828 persons with a population density ranging between 3 to 800 persons per $\mathrm{km} 2$ (KNBS \& SID, 2013). The county has diverse terrain patterns with rainfall ranging between $440 \mathrm{~mm}$ per annum in low lands and over $1900 \mathrm{~mm}$ per annum in the highland areas.

Kilifi county on the other hand, covers a geographical area of $12,245.90 \mathrm{~km}^{2}$ and it is a home of approximately $1,109,735$ people according to the 2009 National census (KNBS, 2009). The temperatures of the county range between $21{ }^{\circ} \mathrm{C}$ during the coldest months (June and July) and $32{ }^{\circ} \mathrm{C}$ during the hottest months (January and February). It has two rainy seasons; April to June (long rains) and October to December (short rains) with annual rainfall ranging between $900 \mathrm{~mm}$ and $1000 \mathrm{~mm}$ per annum.

Little is documented about cassava production in the study area. However, the study area is within the coastal region which is second in production and consumption of cassava in Kenya after the western region. Cassava is mostly produced on small scale in the area with limited value addition, thereby hindering prospects for industrialization. 


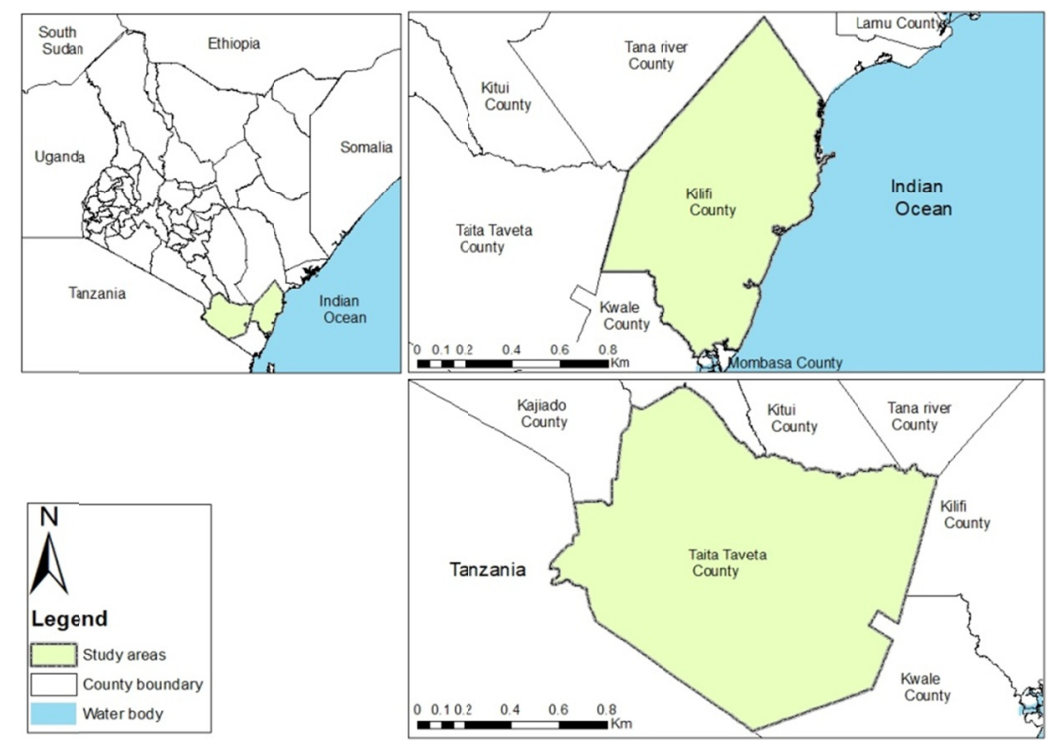

Figure 1. The study area

Source: IEBC (2018).

\subsection{Data Collection Techniques}

(a) Focus Group Discussion (FGD): Focus Group Discussion with different stakeholders along the cassava value chain was contacted prior to the baseline survey. The FGD was focused on cassava production, cassava value added products and cassava markets. Information obtained from focused group discussion was used to inform study results in addition to adjusting the baseline survey question.

(b) Semi-structured questionnaires: During the baseline survey, semi-structured questionnaires were used to collect data on traders and household characteristics, institutional support services, asset ownership and marketing information. The questionnaires were administered face to face, to the respondents by enumerators. Moreover, different observations were made and recorded during data collection including cassava production activities,, cassava harvesting, cassava marketing and value-addition activities.

\subsection{Sampling Procedure and Sample Size}

This study purposefully targeted cassava farmers at the Kenyan Coast and therefore, employed a multi-stage sampling procedure. Kilifi and Taita-Taveta counties were purposively selected due to increased cassava production in the two counties and their strategic location as well as their farming patterns. In Kilifi county, Kaloleni and Kilifi North sub-counties were purposively selected while the whole of Taita-Taveta county was involved in the study. Cassava farming households from selected areas to participate in the study were selected using systematic random sampling method. The selection method involved obtaining a list of cassava farmers from sub-county extension officials and selecting farmers from the list at given intervals depending on required samples per any given area.

According to Israel (1992), and Singh and Masuku (2014); there are four different ways of determining a sample size which include; carrying out a census for finite and small populations, using tested and published tables, imitating sample sizes of other related or similar studies, and using determined formulae to calculate a sample size. Therefore, this study determined the sample size by imitating sample size used in similar/related studies hence total of 250 households were sampled from both counties. The other related studies which have used sample size equal to or close to this including (Florence et al., 2017; Kehinde \& John, 2015; Martey et al., 2012; Musah et al., 2014).

\subsection{Empirical Framework}

A Probit model was used to analyse the determinants of participation decision in cassava marketing by small holder farmers. However, a Logit model can also be applied in this case since both are binary outcome models. A household may decide either to participate in the cassava market or not to participate. The household may also decide to participate in the market from the supply side (selling) or the demand side (buying). 
Binary outcome models are used to estimate the probability that $Y=1$ as a function of the independent variables such that:

$$
\mathrm{p}=\operatorname{pr}[\mathrm{y}=1 \mid \mathrm{x}]=\mathrm{F}\left(\mathrm{x}^{\prime} \beta\right)
$$

The difference between the Logit and Probit models is their functional forms, i.e., $\left[\mathrm{F}\left(\mathrm{x}^{\prime} \beta\right)\right]$. The functional form of the Logit model is the cumulative distribution function (cdf) of the logistic distribution such that:

$$
F\left(x^{\prime} \beta\right)=\wedge\left(x^{\prime} \beta\right)=\frac{e^{\left(x^{\prime} \beta\right)}}{1+e^{\left(x^{\prime} \beta\right)}}=\frac{\exp \left(x^{\prime} \beta\right)}{1+\exp \left(x^{\prime} \beta\right)}
$$

On the other hand, the functional form of the Probit model is the cumulative distribution function (cdf) of the standard normal distribution such that;

$$
F\left(x^{\prime} \beta\right)=\varnothing\left(x^{\prime} \beta\right)=\int_{-\infty}^{\left(x^{\prime} \beta\right)} \emptyset(z) d z
$$

Both the Probit and Logit models are estimated using the maximum likelihood method, and the predicted probabilities are limited between 0 and 1 in both models. Therefore, both the Probit and Logit models can be applied in this case since the marginal effects from both models are almost identical. The only difference is with the coefficients due to the difference in functional forms of the $F$ function such that;

$$
\beta_{\text {logit }}=1.6 \cdot \beta_{\text {probit }}
$$

It is recommended that the Logit model be given priority to the Probit model where the independent variables, in a binary estimation, are too many since it would be difficult for the Probit model to converge. However, this study adopted the use of the Probit model since other related studies have used the model to evaluate factors that influence farmers' market participation decision including (Musah et al., 2014; Abera, 2009; Omiti et al., 2009; Muricho et al., 2015).

$$
\begin{aligned}
\mathrm{CMPD}= & \beta_{0}+\beta_{1} \text { age }+\beta_{2} \text { sex }+\beta_{3} \text { educ }+\beta_{4} \text { famlabor }+\beta_{5} \text { landsize }+\beta_{6} \text { offfarm }+ \\
& \beta_{7} \text { accesscred }+\beta_{8} \text { distmark }+\beta_{9} \text { membership }+\beta_{10} \text { extension }+ \\
& \beta_{11} \text { markexp }+\beta_{12} \text { cassquantity }+\beta_{13} \text { famsize }+\beta_{14} S P+\varepsilon i
\end{aligned}
$$

Where, CMPD is Cassava Marketing Participation Decision and is binary.

\subsection{Diagnostic Tests}

In order for the analysis to be valid, any model used has to satisfy given assumptions. In case the assumptions are not met, some of the problems that may be encountered include; biased coefficient estimates or large standard errors which lead to invalid statistical inferences. In this study, a number of diagnostic tests were done to help identify any problem that may have caused the model not to run effectively or whether the model used was correctly specified.

A specification test was conducted to confirm whether the probability functions of the two models were correctly specified. The model said to be correctly specified if ' 2017). According to the link test results in Appendix $\bar{A}$ the ' $h$ hat' was significant with a $\bar{P}$-value of 0.00 while '_hatsq' was not significant with a P-value of 0.11 thus the model used in this study was correctly specified.

Multicollinearity test was carried out to find whether there was high degree of linear dependency among explanatory variables. Presence of multicollinearity results to coefficients with high standard errors and with few significant variables hence inaccurate estimates (Greene, 2000). Multicollinearity is tested using the Variance Inflation Factor (VIF) and according to Gujarati (2004) and Salisu (2017), any variable with a VIF greater than 10 signifies presence of multicollinearity. The results in Appendix B show no presence of multicollinearity for the variables included in the model and the average VIF was 1.35.

Heteroscedasticity test was conducted to see whether the variance of the error term was constant across observations. Therefore, the Breusch-Pagan test was carried out to determine the variance of the error term (Wooldrige, 2010). The Breusch-Pagan test for the model was significant as shown in Appendix C and therefore, the null hypothesis that the error term had constant variance across observations was rejected. Thus, robust standard errors were used in the model to counter the problem of heteroscedasticity.

The goodness of fit test was applied when testing if sample data fits a distribution from the population. According to Hosmer and Lemeshow (2000), the aim of any overall goodness-of-fit test is to assess whether the fitted model adequately describes the observed outcome experience in the data. Therefore, it's concluded that a model fits well if the differences between the observed and fitted variables are small and if there is no systematic contribution of the differences to the error structure of the given model. Thus, goodness-of-fit tests are usually 
general tests that evaluate the fitted model's overall departure from the observed data. The goodness of fit of a model can be assessed using the $\mathrm{R}^{2}$, the significance of joint probability and the Hosmer-Lemeshow test (HL test/Lfit test). The results in Appendix D for both the $\mathrm{R}^{2}$ and HL test shows that the model is a good fit where the HL test had a P-value of 0.76 .

\section{Results and Discussions}

\subsection{Socio-Economic and Institutional Characteristics of Cassava Farming Households}

Understanding the social, economic and institutional characteristics of smallholder farmers is important since these characteristics greatly influences their decision-making process. Table 1 shows different socio-economic characteristics of cassava farming households at the Kenyan Coast. The study involved cassava farmers that participate and those that do not participate in cassava produce marketing. According to Table 1, majority of the respondents were market participants at 72 percent for the overall sample which accounted for 84 percent from Kilifi county and 60 percent from Taita-Taveta county. The difference in the proportions of market participants between the two counties is a clear indicator that, more cassava farmers from Kilifi county are involved in cassava marketing as compared to those from Taita-Taveta county.

Table 1. Socio-economic characteristics of households by market participation

\begin{tabular}{|c|c|c|c|c|c|c|c|c|c|c|}
\hline & & \multicolumn{3}{|c|}{ Pooled Data } & \multicolumn{3}{|c|}{ Kilifi County } & \multicolumn{3}{|c|}{ Taita-Taveta County } \\
\hline \multicolumn{2}{|l|}{ Variable Category } & $\begin{array}{l}\text { Mrkt } \\
\text { Participant } \\
(\mathbf{n}=\mathbf{1 8 0})\end{array}$ & $\begin{array}{l}\text { Non-mrkt } \\
\text { Participant } \\
(\mathrm{n}=70)\end{array}$ & & $\begin{array}{l}\text { Mrkt } \\
\text { Participant } \\
(\mathrm{n}=\mathbf{1 0 3})\end{array}$ & $\begin{array}{l}\text { Non-mrkt } \\
\text { Participant } \\
(\mathrm{n}=19)\end{array}$ & & $\begin{array}{l}\text { Mrkt } \\
\text { Participant } \\
(\mathrm{n}=77)\end{array}$ & $\begin{array}{l}\text { Non-mrkt } \\
\text { Participant } \\
(\mathrm{n}=\mathbf{5 1})\end{array}$ & \\
\hline \multicolumn{2}{|l|}{ Continuous Variables } & \multicolumn{2}{|c|}{ Mean (SD) } & t-test & \multicolumn{2}{|c|}{ Mean (SD) } & t-test & \multicolumn{2}{|c|}{ Mean (SD) } & t-test \\
\hline \multicolumn{2}{|l|}{ Years of School } & $6.03(4.57)$ & $8.54(3.78)$ & $4.08^{* * *}$ & $4.88(4.59)$ & $7.58(3.69)$ & $2.42 * *$ & $7.57(4.08)$ & $8.90(3.79)$ & $1.86^{*}$ \\
\hline \multicolumn{2}{|l|}{ Farmer's Age in Years } & $47.99(14.51)$ & $50.61(14.73)$ & 1.28 & $47.78(15.92)$ & $46.58(14.55)$ & -0.31 & $48.27(12.49)$ & $52.12(14.66)$ & 1.59 \\
\hline \multicolumn{2}{|l|}{ Household size } & $6.55(2.81)$ & $6.94(3.3)$ & 0.94 & $7.22(3.05)$ & $7.89(4.23)$ & 0.82 & $5.65(2.14)$ & $6.59(2.99)$ & $2.07 * *$ \\
\hline \multicolumn{2}{|l|}{ Years of Experience } & $8.94(6.85)$ & $8.01(5.43)$ & -1.02 & $7.97(7.24)$ & $6.63(5.49)$ & -0.77 & $10.25(6.1)$ & $8.53(5.37)$ & $-1.64^{*}$ \\
\hline \multicolumn{2}{|l|}{ Log Quantity harvested } & $7.33(1.31)$ & $5.64(0.82)$ & $10.01 * * *$ & $7.69(1.19)$ & $6.15(0.79)$ & $-5.40 * * *$ & $6.84(1.32)$ & $5.44(0.75)$ & $-6.83 * * *$ \\
\hline \multicolumn{2}{|c|}{ Distance to the Market centre } & $7.93(3.93)$ & $12.28(2.94)$ & $8.37 * * *$ & $6.67(3.82)$ & $12.32(2.47)$ & $6.20 * * *$ & $9.62(3.44)$ & $12.26(3.12)$ & $4.41 * * *$ \\
\hline \multicolumn{2}{|l|}{ Dummy Variables } & \multicolumn{2}{|c|}{ Percentage } & $\chi^{2}$-value & \multicolumn{2}{|c|}{ Percentage } & $\chi^{2}$-value & \multicolumn{2}{|c|}{ Percentage } & $\chi^{2}$-value \\
\hline \multirow{2}{*}{ Sex of head of Household } & Male & 67.49 & 32.51 & $10.91 * * *$ & 82.47 & 17.53 & 1.37 & 53.77 & 46.23 & $10.48 * * *$ \\
\hline & Female & 91.49 & 8.51 & & 92.00 & 8.00 & & 90.91 & 9.09 & \\
\hline \multirow{2}{*}{ Extension Services } & Yes & 93.14 & 6.86 & $38.18 * * *$ & 92.42 & 7.58 & $7.00 * * *$ & 94.44 & 5.56 & $24.57 * * *$ \\
\hline & No & 57.43 & 42.57 & & 75.00 & 25.00 & & 46.74 & 53.26 & \\
\hline \multirow{2}{*}{ Credit Access } & Yes & 90.74 & 9.26 & $12.00 * * *$ & 94.87 & 5.13 & $4.76^{* *}$ & 80.00 & 20.00 & $4.76^{* *}$ \\
\hline & No & 66.84 & 33.16 & & 79.52 & 20.48 & & 57.52 & 42.48 & \\
\hline \multirow{2}{*}{ Off-farm activity } & Yes & 71.91 & 28.09 & 0.00 & 76.74 & 23.26 & $2.98^{*}$ & 67.39 & 32.61 & 1.57 \\
\hline & No & 72.05 & 27.95 & & 88.61 & 11.39 & & 56.10 & 43.90 & \\
\hline
\end{tabular}

Note. $* * * * *$, and $*$ are significant levels at $1 \%, 05 \%$ and $10 \%$ respectively.

Source: Survey Data (2017).

There was a significant difference in the average years of schooling between the market participants and non-market participants at the Kenyan coast for the pooled data and more so, in Kilifi county than in Taita-Taveta county. Non-market participants have a higher level of formal education than the market participants. The higher level of education can explain why the non-market participants do not participate in the market since they allocate more of their time in doing other off-farm income generating activities in line with their profession.

The mean household size was found to be significantly different between market participants and non-market participants in Taita-Taveta county only. Non-market participants had a bigger household size as compared to market participants in the county. A bigger household size means more people to feed and therefore the cassava produced is only used for home consumption as the household size increases and no surplus for marketing.

The difference in average years of farming experience between market participants and non-market participants was only significant in Taita-Taveta county. Market participants had more experience in cassava farming than non-market participants and therefore were more informed on different aspects of cassava farming. Experience comes along with trial and error experimentation on different varieties, knowledge on different market 
channeling and thereafter value addition. According to Egbetokun (2012), an increase in years of farming experience increases smallholder farmers' market orientation.

The average quantity harvested was found to significantly differ between market participants and non-market participants. Farmers that participate in the market harvest larger amounts of cassava as compared to those who don't participate in the market. This is a clear indicator that those farmers who participate in cassava marketing have allocated more resources to cassava production as compared to those who do not participate in cassava marketing since the results also show that there is no difference in land size owned by the two groups.

The overall average distance from farms of non-market participants to the nearest market, was found to be significantly longer than the average distance from farms of market participants to the nearest market. Longer distances to the nearest market mean higher production and transaction costs for participating in cassava marketing and therefore leading to lower returns. This is consistent with the results of Ouma et al. (2010), who found out that increase in time taken by smallholder farmers to reach the nearest market, reduces their probability to participate in marketing. In addition, Ouma et al. (2010) argues that, farming households located in remote areas have poor market access leading to increased transaction costs in terms of marketing, transport and information costs.

Results in Table 1 also show an overall significant difference in proportion of the sex of head of households between market participants and non-market participants and more so in Taita-Taveta. Generally, most household at the Kenyan coast are male headed (KNBS \& SID, 2013) but to the contrary, a larger proportion of cassava farming female headed households participate in cassava marketing as compared to male headed households. This means that, female headed households are more likely to participate in cassava marketing than male headed households.

The proportion of extension services received between market and non-market participants is also significantly different in the two counties and therefore in the region. A higher proportion of market participants receive extension services from different sources (research institutions, NGOs, Extension officers, other farmers) as compared to non-market participants. Provision of extension services means an increase in knowledge about the subject matter and therefore increase in efficiency of production.

Table 1 shows a significant difference in the proportion between market and non-market participants who have access to credit. Farmers from both Kilifi and Taita-Taveta counties who participate in cassava marketing have a higher access to credit services as compared to non-participants. The overall proportion in the region shows a more significant difference in credit access at the Kenyan coast between market participants and non-market participants thus a higher access to credit services by market participants in the region.

The difference in proportion between market and non-market participating farmers who engaged in off-farm activities was significant in Kilifi county only. A larger proportion of farmers who don't participate in cassava marketing, participate in off-farm activities as compared to market participants. This means that farmers who have other income generating activities other than farming, are forced to allocate some of their time in carrying out those activities and therefore are unlikely to participate in cassava marketing.

On the other hand, there were no significant differences in average age nor size of land owned among market participants and non-market participants. This means that, both groups of farmers who participate or don't participate in cassava marketing have almost similar age and farm size on average.

\subsection{Determinants of Participation Decision in Cassava Marketing}

Most of the smallholder cassava farmers ( 72 percent) participate in cassava marketing implying that cassava is an income generating crop for most of the farmers. The farmers make the decision of either participating or not participating in cassava marketing based on their rational nature which is always geared towards maximize utility. However, the decision to participate or not participate in cassava marketing by any farmer is said to be influenced by either socio-economic or institutional factors. Therefore, Table 2 below, shows different socio-economic and institutional factors, and how they influence smallholder farmers' decision to participate or not participate in cassava marketing. The marginal effects (dy/dx), have been used to interpret the magnitude of effect where a significant unit change in the specified variable occurred. 
Table 2. Probit model results for determinants of participation decision in cassava marketing

\begin{tabular}{|c|c|c|c|c|c|c|c|c|c|}
\hline \multirow[b]{2}{*}{ Mkt_Part } & \multicolumn{3}{|c|}{ Pooled Data } & \multicolumn{3}{|c|}{ Kilifi County } & \multicolumn{3}{|c|}{ Taita-Taveta County } \\
\hline & $d y / d x$ & Coef. & $\begin{array}{l}\text { Robust } \\
\text { Std. Err. }\end{array}$ & $d y / d x$ & Coef. & $\begin{array}{l}\text { Robust } \\
\text { Std. Err. }\end{array}$ & $d y / d x$ & Coef. & $\begin{array}{l}\text { Robust } \\
\text { Std. Err. }\end{array}$ \\
\hline Sex of the Farmer & -0.04 & -0.19 & 0.27 & -0.06 & $-0.95 *$ & 0.47 & 0.05 & 0.18 & 0.41 \\
\hline Sex of the $\mathrm{HoH}$ & -0.12 & $-0.92 * * *$ & 0.37 & 0.01 & 0.15 & 0.55 & -0.30 & $-1.83 * * *$ & 0.67 \\
\hline Yrs of schooling & -0.01 & $-0.07 * *$ & 0.03 & 0.00 & -0.08 & 0.05 & -0.02 & $-0.07 *$ & 0.04 \\
\hline Credit Access & 0.04 & 0.24 & 0.34 & 0.06 & $1.18 * *$ & 0.57 & 0.04 & 0.16 & 0.48 \\
\hline Family Labor No. & 0.01 & 0.04 & 0.07 & 0.00 & 0.04 & 0.11 & 0.00 & 0.01 & 0.11 \\
\hline Off-farm activity & -0.04 & -0.21 & 0.25 & -0.08 & $-0.94 * *$ & 0.45 & 0.04 & 0.13 & 0.33 \\
\hline Farmer Age & 0.00 & -0.01 & 0.01 & 0.00 & 0.02 & 0.01 & -0.01 & $-0.03 * *$ & 0.01 \\
\hline Household size & -0.02 & $-0.12 * *$ & 0.05 & -0.01 & $-0.10^{*}$ & 0.06 & -0.04 & $-0.14 *$ & 0.08 \\
\hline Ext services & 0.14 & $0.84 * * *$ & 0.31 & 0.00 & 0.08 & 0.41 & 0.35 & $1.65^{* * *}$ & 0.50 \\
\hline Farm Size Owned & -0.01 & $-0.06^{* *}$ & 0.03 & -0.01 & $-0.10^{* *}$ & 0.05 & -0.01 & -0.03 & 0.04 \\
\hline Selling Price & 0.01 & $0.05 *$ & 0.03 & 0.00 & 0.02 & 0.03 & 0.01 & 0.02 & 0.06 \\
\hline LogQuantity harv & 0.17 & $0.90 * * *$ & 0.12 & 0.06 & $0.97 * * *$ & 0.20 & 0.31 & $1.06^{* * *}$ & 0.18 \\
\hline \multirow[t]{6}{*}{ Constant } & & -4.91 & 1.55 & & -5.86 & 2.14 & & -2.99 & 2.72 \\
\hline & \multicolumn{3}{|c|}{ Number of observations $=250$} & \multicolumn{3}{|c|}{ Number of observations $=122$} & \multicolumn{3}{|c|}{ Number of observations $=128$} \\
\hline & \multicolumn{3}{|c|}{ Wald chi2 $(12)=74.49$} & \multicolumn{3}{|c|}{ Wald chi2 $(12)=32.01$} & \multicolumn{3}{|c|}{ Wald chi2 $(12)=57.23$} \\
\hline & \multicolumn{3}{|c|}{ Prob $>$ chi $2=0.00$} & \multicolumn{3}{|c|}{ Prob $>$ chi $2=0.00$} & \multicolumn{3}{|c|}{ Prob $>$ chi $2=0.00$} \\
\hline & \multicolumn{3}{|c|}{ Pseudo $R^{2}=0.47$} & \multicolumn{3}{|c|}{ Pseudo R2 $=0.43$} & \multicolumn{3}{|c|}{ Pseudo R2 $=0.54$} \\
\hline & \multicolumn{3}{|c|}{ Log pseudolikelihood $=-78.93$} & \multicolumn{3}{|c|}{ Log pseudolikelihood $=-30.16$} & \multicolumn{3}{|c|}{ Log pseudolikelihood $=-39.66$} \\
\hline
\end{tabular}

Note. ${ }^{* * *},{ }^{* *}$, and $*$ are significant levels at $1 \%, 05 \%$ and $10 \%$ respectively.

Source: Survey Data (2018).

The results in Table 2 show that, female headed cassava farming households in Taita-Taveta and at the coastal region (pooled data), were more likely to participate in cassava marketing at 1 percent significance level. Female farmers from Kilifi County were also more likely to participate in cassava marketing at 10 percent significance level. This result is in line with the findings of Okoye et al. (2010), in his study on Transaction Costs and Market Participation by Small-Holder Cassava Farmers in South-Eastern Nigeria. Therefore, an increase by 1 unit of cassava farmers from Taita-Taveta who come from a female headed household increases the probability of participation in cassava marketing by 30 percent. Similarly, an increase in female headed households by 1 unit at the Kenyan coast as a whole, increases the probability of participation in cassava marketing by 12 percent. The female headed households are more likely to participate in the market because farming activities at the coast are mostly carried out by females unlike men who prefer other jobs. Therefore, the male headed households may make farm allocation decision based on traditionally farmed crops, regardless of utility maximization. On the other hand, female headed households may easily adopt new crops on their farms and allocate them a larger proportion of land to maximize utility since they are engaged directly in the farming activities.

Years of schooling negatively affect market participation. Okoye et al. (2010), had a similar observation and argued that educated farmers are more likely to be autarkic. Hence, a cassava farmer at the coast who increases his years of schooling by one year, is 1 percent less likely to participate in cassava marketing. Similarly, a unit increase in years of schooling by a farmer in Taita-Taveta county, results to a 7 percent less likelihood of participating in cassava marketing. Formal education has a negative influence on cassava marketing because, people who are educated go for white collar jobs or formal employment where they allocate much of their time and just a little for farming. The coast region has low levels of education (KNBS \& SID, 2013) and therefore, the few educated people tend to get white collar jobs faster within the region hence a more constant income as compared to farming.

Credit access in Kilifi county had a significant influence on market participation at 5 percent confidence level. This result coincides with that of Adjimoti (2013), who found a positive relationship between credit and market participation in his study on Market Participation among Cassava Value Chain Actors in Rural Benin. Accordingly, many cassava farmers from Kilifi easily access credit for farming purposes from their farmer groups which are well structured. An increase by one unit in the number of farmers in Kilifi county who have access to credit services makes them 6 percent more likely to participate in cassava marketing. This is because access to credit enables farmers to perform different farming activities at the right time of the year (Gershon et al., 1990; Fischer, 2012). According to focused group discussion, the virtue of group membership also helps to monitor the use of this credit to ensure that it serves the right purpose it was borrowed for. 
Farmers in Kilifi county who participated in other income generating activities other than farming were less likely to participate in cassava marketing. The results in Table 2 show that, farmers in Kilifi county who participated in off-farm activities were 8 percent less likely to participate in cassava marketing. This is because, farmers are rational in nature and they would allocate more of their time on those activities that generate higher utility. Therefore, those not participating in other off-farm income generating activities will allocate all their time in farming while those participating in other off-farm activities will allocate more of their time to those activities maximizing their incomes.

Older farmers in Taita-Taveta county are less likely to participate in cassava marketing. Kemisola et al. (2013), also found a similar result in his study on Market Orientation of cassava farmers in Nigeria and argued that as farmers get older their ability to perform farming activities reduces. Similarly, Adjimoti (2013), had coinciding results while Okoye et al. (2010), results were on the contrary. According to the results in Table 2, an increase in the famers' age by 1 year in Taita-Taveta county leads to a 1 percent less likelihood by that farmer to participate in cassava marketing. Abele et al. (2007), also found a negative significant relationship between age and intensity of adoption of new cassava varieties and argued that older farmers were conservative in nature and held on traditional cassava varieties. The low adoption of new technologies by older farmers means low production and low productivity thus high production costs resulting from production inefficiencies and therefore low or no market participation.

The results also show that, the household size had a negative and significant influence on cassava marketing. An increase in the number of people in the household by 1 person, reduces the likelihood of participating in cassava marketing at the coast by 2 percent, 1 percent in Kilifi and 4 percent in Taita-Taveta. Larger households are less likely to participate in cassava marketing because, they are more likely to have a larger dependency ratio and therefore, most of what is produced is consumed at the household level. This result is in contrast with that of Gani and Adeoti (2011), who found a positive relationship between family size and market participation. Gani and Adeoti (2011), argued that larger households reduce production costs by providing family labour.

Extension services have a significant and positive influence on market participation. Provision of extension services at the Kenyan coast increases the probability of cassava farmers to participate in cassava marketing by 14 percent. Subsequently, extension services in Taita-Taveta county increases the probability of cassava farmers to participate in cassava marketing by 35 percent. The extension services are provided by different entities including government and parastatal officials, non-governmental organizations and other farmers. Extension services have a huge influence on participation in cassava marketing because they are mainly provided by experts in different areas along the whole value chain. Information provided helps farmers to make important decisions on the level of production, processing, marketing and consumption. Different studies on factors influencing farmers' participation in cassava marketing have found similar results including (Sarka, 2017; Adjimoti, 2013; Gani \& Adeoti, 2011; Okoye et al., 2010).

The larger the piece of land a cassava farmer has at the coast, the less likely they are to participate in cassava marketing. Results show that, an increase in farm size by 1 acre at the coast, reduces the probability of engaging in cassava marking by 6 percent. Similarly, the probability of participating in cassava marketing is reduced by 10 percent when the farm size increases by 1 acre in Kilifi county. This result agrees with that of Egbetokun and Omonona (2012), who found a negative relationship between farm size and market participation of farmers in food markets in Nigeria. However, Onya et al. (2016), had a contrary result that showed a positive relationship between farm size and market participation. Therefore, an increase in farm size at the Kenyan coast has a negative influence on participation in cassava marketing because, farmers with larger farms tend to farm other crops that they perceive have a lower opportunity cost than cassava and result to higher utilities. During the focused group discussion, farmers ranked maize first as their preferred crop to cultivate. In addition, farmers also prefer to keep cassava production at low levels because of poorly organized cassava marketing system, the perishable nature of cassava tubers and inadequate knowledge on value addition.

The selling price had a significant and positive influence on participation in cassava marketing. This result was consistent with that of Enete and Igbokwe (2009), on Cassava Market Participation Decisions of Producing Households in Africa. An increase in price by 1 Kenyan shilling at the coast, results to 1 percent probability that a farmer will participate in cassava marketing. More farmers would participate in the market to make profits as a result of increased prices, since farmers are rational in nature and therefore utility maximizing agents. This means that, all other factors held constant, the marketable supply will increase and therefore, this result is in line with the law of supply. 
The results in Table 2 show that, cassava farmers were significantly influenced at 1 percent level of significance to participate in cassava marketing by the quantity of cassava they harvested. Sarka (2017), and Gani and Adeoti (2011), also found a consistent in their studies on factors influencing cassava farmers participation in cassava market in Ethiopia and Nigeria respectively. An increase in the quantity harvested by 1 kilogram resulted to 17 percent increase in market participation by cassava farmers at the cost. Similarly, 1kilogram increase in the quantity of cassava harvested leads to 6 percent and 31 percent increase in market participation by cassava farmers in Kilifi and Taita-Taveta counties respectively. This is because, an increase in quantity harvested holding other factors constant, means an increase in surplus and therefore, market participation provides the best avenue to dispose the excess produce while maximizing farmers' utility.

\section{Policy Implications}

Policy implications derived from this study indicate that processes of accessing credit and extension services should be fast, easy and favourable to cassava farmers. This is because, cassava farmers who accessed credit and extension services were more likely to participate in cassava marketing. Since the quantity of cassava produced and the market price of cassava products positively influenced market participation, the extension services should be geared towards increasing cassava production and creating awareness on best marketing channels for the farm produce. Similarly, farmers should be encouraged to practice family planning to maintain small family sizes. This is because, an increase in the size of household size, reduces the likelihood of participating in cassava marketing, thereby reducing farm incomes to enable access to essential non-farm goods and services. Therefore, processes should be put in place for enhancing creation of awareness among cassava farmers on the importance of keeping small family size.

\section{Conclusion and Recommendations}

Cassava production and marketing is important for improving food security, income generation and industrialization. The decision to participate in cassava marketing is pegged on social, economic and institutional factors in environments within which different actors operate. The results show that cassava marketing has a great potential and cassava production can be improved by provision of appropriate incentives to farmers. The incentives should be in form of ease to credit access and access to extension services to train and improve farmers' knowledge on cassava production. Increasing cassava market prices, also motivates farmers to increase their participation in the market. The incentives should target female headed households or female farmers since they are more likely to empress them. Therefore, provision of appropriate incentives like extension services on pest management practices and seed, quality inputs and infrastructure for improving market accessibility would encourage increased participation in cassava marketing and improved farm incomes.

\section{Acknowledgements}

We thank all the respondents for their time and volunteering to be part of the study. We also acknowledge the work of the data collection team and field guides. Finally, our special gratitude goes to the Regional Universities Forum for Capacity Building in Agriculture (RUFORUM) for funding this study.

\section{References}

Abele, S., Twine, E., Ntawuruhunga, P., Baguma, Y., Kanobe, C., \& Bua, A. (2007). Development and dissemination of improved cassava varieties in Uganda: Analysis of adoption rates, variety attributes and speed of adoption. AAAE Conference Proceedings (pp. 479-482).

Abera, G. (2009). Commercialization of Smallholder Farming: Determinants and Welfare Outcomes: A Cross-sectional study in Enderta District, Tigrai.

Burrett, C. B. (2008). Small holder market participation: Concepts and evidence from Eastern and Southern Africa. Food Policy, 33, 299-317. https://doi.org/10.1016/j.foodpol.2007.10.005

De Janvry, A., Fafchamps, M., \& Sadoulet, E. (1991). Peasant household behaviour with missing markets: Some paradoxes explained. The Economic Journal, 101(409), 1400-1417. https://doi.org/10.2307/2234892

Dunstan, S., \& Chuma, E. (2017). Cassava cultivation in sub-Saharan Africa. Burleigh Dodds Science Publishing Limited.

Egbetokun, O. A., \& Omonona, B. T. (2012). Determinants of farmers' participation in food market in Ogun State, Nigeria. Global Journal of Science Frontier Research Agriculture and Veterinary Sciences, 12(9).

Enete, A. A., \& Igbokwe, E. M. (2009). Cassava Market Participation Decisions of Producing Households in Africa. Tropicultura (pp. 129-136). Department of Agricultural Economics, University of Nigeria, Nsukka (UNN), Nigeria. 
FAOSTAT. (2017): Retrieved February 20, 2019, from http://www.fao.org/faostat/en/\#data/QC

Fischer, E., \& Qaim, M. (2012). Linking Smallholders to Markets: Determinants and Impacts of Farmer Collective Action in Kenya. World Development, 40(6), 1255-1268. https://doi.org/10.1016/j.worlddev. 2011.11.018

Florence, A., Peter, D., \& Maximilian, W. (2017). Characterization of the Levels of Cassava Commercialization Among Smallholder Farmers in Kenya: A multinomial regression approach. African Journal of Agricultural Research, 12(41). 3024-3036. https://doi.org/10.5897/AJAR2017.12634

Gani, B. S., \& Adeoti, A. I. (2011). Analysis of Market Participation and Rural Poverty among Farmers in Northern Part of Taraba State, Nigeria. Journal of Economics, 2(1), 23-36. https://doi.org/10.1080/ 09765239.2011.11884934

Gershon, F., Lawrence, J. L., Justin, Y. L., \& Xiaopeng, L. (1990). The Relationship between Credit and Productivity in Chinese Agriculture: A Microeconomic Model of Disequilibrium. American Journal of Agricultural Economics, 72(5), 1151-1157. https://doi.org/10.2307/1242524

Gilbert, O. A. (2014). Market Participation among Cassava Value Chain Actors in Rural Benin. Retrieved from http://www.ecoasso.org/articles/Adjimoti_Gilbert.pdf

Goetz, S. (1992). A Selectivity Model of Household Food Marketing Behavior in Sub-Saharan Africa. American Journal of Agricultural Economics, 74, 444-452. https://doi.org/10.2307/1242498

Greene, W. (2002). Econometric Analysis (4th ed.) New York, NY: Macmillan Publishing Company.

Gujarati, D. (2004). Basic Econometrics (4th ed.). New York, NY: The McGraw-Hill Companies.

Hosmer, D. W. Jr., \& Lemeshow, S. (2000). Applied Logistic Regression (2nd ed.). New York: Wiley. https://doi.org/10.1002/0471722146

IEBC. (2018). IEBC County Boundary Maps. https://www.google.com/search?q=iebc+county+boundary+ maps\&tbm $=$ isch\&source $=$ univ\&client $=($ accessed $7 \mathrm{th} / 4 / 2019)$

Israel, G. (1992). Determining sample size: Sampling the evidence of Extension Program Impact. Program Evaluation and Organizational Development, Institute of Food and Agricultural Sciences, University of Florida.

KAPAP (Kenya Agricultural Productivity and Agribusiness Project). (2012). Deepening investments in the development of cassava value chain.

Kehinde, Y. O., \& John, O. O. (2015). Production and Marketing Performance of Farmers Participating in Cassava Initiative across Agricultural Zones in Nigeria. Journal of Economics and Sustainable Development, 6(6).

Kemisola, O. A., Olorunsomo, S. O., \& Nwauwa, L. O. (2013). Determinants of Market Orientation Among Smallholders Cassava Farmers in Nigeria. Global Journal of Management and Business Research Finance, 13(6).

Key, N., Sadoulet, E., \& De Janvry, A. (2000). Transaction costs and agricultural household supply response. American Journal of Agricultural Economics, 83, 345-259. https://doi.org/10.1111/0002-9092.00022

KNBS \& SID (Society for International Development). (2013). Exploring Kenya's Inequality. Pulling Apart or Pooling Together?

KNBS (Kenya National Bureau of Statistics). (2009). National Census.

Koplez; IITA. (2009). Unraveling Cassava's Problems. Transforming African Agriculture. Retrieved August 20, 2018, from http://r4dreview.iita.org/index.php/page/22/?orderby=views

Martey, E., Al-Hassan, R. M., \& Kuwornu, J. K. M. (2012). Commercialization of Smallholder Agriculture in Ghana: A Tobit regression analysis. African Journal of Agricultural Research, 7(14). 2131-2141.

Muricho, G. S., Damiano, M., \& Fredrick, S. (2015). Determinants of agricultural commercialization and its impacts on welfare among smallholder farmers in Kenya (PhD Theses of the University of Nairobi, Nairobi).

Musah, A., Yaw, B., \& Seini, W. (2014). Market participation of smallholder maize farmers in the upper west region of Ghana. Afr. J. Agric. Res., 9(31), 2427-2435. https://doi.org/10.5897/AJAR2014.8545 
Okoye, B. C., Onyenweaku, C. E., \& Ukoha, O. O. (2010). An Ordered Probit Model Analysis of Transaction Costs And Market Participation by Small-Holder Cassava Farmers in South-Eastern Nigeria. Munich Personal RePEc Archive (Paper No. 26114).

Omiti, M., Nyanamba, D., \& Mccullough, E. (2009). Factors Influencing the Intensity of Market Participation by Smallholder Farmers: A Case Study of Rural and Peri-urban areas of Kenya.

Onya, S. C., Samuel, E. O., Ikenna, V. E., \& Francis C. O. (2016). Market Participation and Value Chain of Cassava Farmers in Abia State. Journal of Scientific Research \& Reports, 12(1), 1-11. https://doi.org/ $10.9734 / \mathrm{JSRR} / 2016 / 27950$

Ouma, E., Jagwe, J., Obare, G. A., \& Abele, S. (2010). Determinants of smallholder farmers' participation in banana markets in Central Africa: the role of transaction costs. Agricultural Economics, 41(2), 111-122. https://doi.org/10.1111/j.1574-0862.2009.00429.x

Salisu, A. A. (2017). Binary Choice Models. Centre for Econometric \& Allied Research (CEAR), University of Ibadan.

Sarka, S. (2017). Factor Affecting Farmers' Market Participation Decision and Amount of Cassava Supplied to the Market in Wolaita Zone, Snnpr, Ethiopia. Journal of Economics and Sustainable Development, 8(7).

Singh, A., \& Masuku, M. (2014). Sampling Techniques and Determination of Sample Size in Applied Statistics Research. International Journal of Economics, Commerce and Management, United Kingdom. Retrieved from http://ijecm.co.uk/wp-content/uploads/2014/11/21131.pdf

Wooldrige, J. (2010). Econometric Analysis of Cross sectional and Panel Data. The MIT Press, Cambridge Massachusetts.

YPARD (Young Professional for Agricultural Development). (2014). Cassava production in Africa-Turning minors to majors. Retrieved April 18, 2018, from https://ypard-.net/news/cassava-production-africaturning-minors-majors

\section{Appendix A}

\section{Specification Test}

\begin{tabular}{llll}
\hline Mkt_Part & Coef. & Std. Err. & P>z \\
\hline _hat & 1.11 & 0.15 & 0.00 \\
_hatsq & -0.11 & 0.07 & 0.11 \\
_cons & 0.07 & 0.13 & 0.59 \\
\hline
\end{tabular}

\section{Appendix B}

\section{Multicollinearity Test}

\begin{tabular}{lll}
\hline Variable & VIF & 1/VIF \\
\hline Fam_Labor_No & 1.46 & 0.68 \\
Sex of Farmer & 1.46 & 0.68 \\
Farmers'Age & 1.42 & 0.70 \\
House_size & 1.41 & 0.71 \\
Sex_HoH & 1.38 & 0.73 \\
Credit_acces & 1.38 & 0.73 \\
logQ_harvested & 1.36 & 0.74 \\
Educ_Years & 1.35 & 0.74 \\
Farm_Size & 1.33 & 0.75 \\
Ext_services & 1.33 & 0.75 \\
Offfarm_activity & 1.19 & 0.84 \\
Selling_Price & 1.08 & 0.93 \\
\hline Mean VIF & $\mathbf{1 . 3 5}$ & \\
\hline
\end{tabular}




\section{Appendix C}

\section{Heteroscedasticity Test}

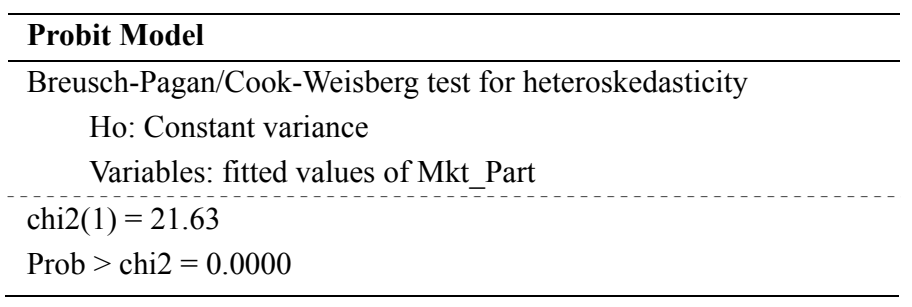

\section{Appendix D}

\section{Goodness of Fit}

\begin{tabular}{ll}
\hline $\mathbf{R}^{2}$ results & Hosmer-Lemeshow test $($ HL test/Lfit test) results \\
\hline Number of observations $=250$ & Number of observations $=250$ \\
Wald chi2 $(12)=74.49$ & Number of covariate patterns $=246$ \\
Prob $>$ chi2 $=0.00$ & Pearson $\operatorname{chi} 2(233)=217.20$ \\
Pseudo $R^{2}=0.47$ & Prob $>\operatorname{chi} 2=0.7637$ \\
Log pseudolikelihood $=-78.93$ & Number of observations $=250$ \\
\hline
\end{tabular}

\section{Copyrights}

Copyright for this article is retained by the author(s), with first publication rights granted to the journal.

This is an open-access article distributed under the terms and conditions of the Creative Commons Attribution license (http://creativecommons.org/licenses/by/4.0/). 